\title{
REVIEW STUDY OF WESTERN WORLD LIFESTYLE FROM THE AYURVEDIC PERSPECTIVE
}

\author{
Vd. Jayashree Patil 1, Vd. Nisar R Shaikh ${ }^{* 2}$ \ \\ ${ }^{1}$ HOD, Guide, Professor Swasthvritta Department, LRP Ayurvedic Medical College, Research Centre \\ and P.G. institute, Islampur, Sangli, Maharashtra 415409, India \\ ${ }^{*}$ M.D. scholar, Swasthvritta Department, LRP Ayurvedic Medical College, Research Centre and P.G. \\ institute, Islampur, Sangli, Maharashtra 415409, India
}

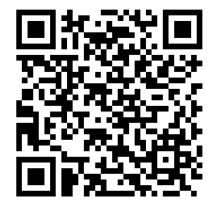

DOI: https://doi.org/10.29121/granthaalayah.v8.i9.2020.1009

Article Type: Research Article

Article Citation: Vd. Jayashree Patil, and Vd. Nisar R Shaikh. (2020).

REVIEW STUDY OF WESTERN

WORLD LIFESTYLE FROM THE

AYURVEDIC PERSPECTIVE.

International Journal of Research -

GRANTHAALAYAH, 8(9), 107-112.

https://doi.org/10.29121/granthaa

layah.v8.i9.2020.1009

Received Date: 08 August 2020

Accepted Date: 29 September 2020

Keywords:

Western Lifestyle

Ayurveda

Modifications

Deep Connections

Agni

\begin{abstract}
This is for us to look at the western lifestyle through the lenses of ayurveda and it's revived modified forms in today's world. We are seeing the world from a totally different perspective where modern world has its roots to the start, changes needs changes to fulfill each other's needs. And for human's survival has always been the first priority to attend to. Western lifestyle is necessarily an adaptation of ayurvedic principles and this very thought gives support to the claim of universal ayurveda.
\end{abstract}

\section{INTRODUCTION}

We are facing so many changes in our lives due to blind following of western lifestyle, right from eating, sleeping, sitting, travelling, everything is changing and getting modified, to a way that is making the human being more and more sick. When we look at the western lifestyle it is totally forgotten ayurveda, it is what we see and think. But is there anything that is similar too? Do we find the similarities anywhere in ayurveda and western lifestyle?

It's like comparing two opposite poles.

What is ayurveda exactly? What is the meaning of ayurveda?

The word ayurveda is made up of two words, 'Ayur' and 'veda'. 'Ayur' means life and 'veda' means science. The science of life is ayurveda. This is the in-built nature, a nature which every human being possess, that nature is called ayurveda. And life means every life, Indian life as well as western life.

As we believe that Ayurveda exists right from the beginning of the world, it's principles are used everywhere and in every form but some feel that, it's the loss of ayurveda on the surface in the western lifestyle but the case is

(C) 2020 The Author(s). This is an open access article distributed under the terms of the Creative Commons Attribution License, which permits unrestricted use, distribution, and reproduction in any medium, provided the original author and source are credited. 
not so. If we study our matter deeply we will find relevant findings that in the western countries ayurveda is still used in a modified way to adjust with the environment they face. We have researched about how the western world has modified the ayurvedic scriptures and have not violated them.

How is ayurveda, an Indian science universal? When we look at the lifestyle of people in the western today, and when we read the ayurvedic scriptures about lifestyle, there are no similarities in their ways or living, eating, or any day to day life, they are contrasting to the scriptures, but this is only the surface study, it is when we study the deep roots of each new and contrasting ways from ayurveda of living, we will find the reality behind everything, the true roots that were kept in mind while making the revolutionary changes.

Talking with the experience right from studying the scriptures and observing the lifestyles deeply on my own, the idea of finding the similarities and connection. How even after being very different to start with they are just similar to our ways, just modified according to the need of the environment/ geographical condition. Researching on the internet with trying different questions until I have found out what is quite relevant, I searched through websites, with relevant information regarding to the topics in the paper.

\section{MATERIAL AND METHODS}

1) Ashatanga hridayam

2) Charak samhita

3) Internet browsing through various websites

\subsection{METHOD}

observational study

\subsection{AIM}

1) To study the ayurveda in the western world.

2) Modification of ayurvedic scriptures in day to day life.

\section{RESULTS}

\subsection{AYURVEDA}

We believe that ayurveda is there since the beginning of the world, so somehow the whole world is following the ayurvedic principles. Now if we see the present situation we see that most of the western lifestyle is totally opposite of the ayurvedic lifestyle, so how do we justify ayurveda is universal?

1) Eating half baked bread like pizza, burger, breads with cheese kind of stuff

2) Excessive use of milk products like cheese, curd etc

3) Use of salad and raw food including lots of fruits

4) Sitting on table and chair for eating

These are few of traditions we found in western world which are not in tune with concepts given in ayurveda.

Even if today its form is very much twisted and has taken role of junk eating but originally idea was pure ayurvedic in nature.

Even if we do not have proof, the westerners in olden times were using therapeutic science which is in ayurveda. 
Vd. Jayashree Patil, and Vd. Nisar R Shaikh.

\subsection{THE INVENTIONS AND REVOLUTIONS}

\subsubsection{THE HALF-BAKED BREAD}

When we see the use of curd and bread pizza and cheese all these things it is important to understand how these things got into the system.

We need to understand the requirements of the particular place that kept on changing.

If we see the weather conditions of Europe it is extremely cold most of the time, even the summer's time is not much hot. Being in cold conditions for longer time period, the internal gastric fire is certainly very high of the people there.

To satisfy the high fire, or hunger, the consumption of more food is required. So, if a resident of such place who has a good amount of fire was to eat chapatti, they will easily eat 10 to 12 chapattis because it is fully cooked and easy to digest. It simply means that they will need more amount of grains or food to fulfill their needs.

Even if we look from the perspective of fuel consumption lot much fuel will be required to cook so much of food. During the old times, when wood was used to cook food ${ }^{1}$, they were looking for a way to consume less of wood and cook enough food as well, but due to extreme climatic conditions, if we count in the conditions of wars, inflammation, droughts and famines created by humans and some by nature itself, the situation was much worse; there was a lot of scarcity of food supply2; Somehow to manage the high amount of internal fire, and to consume less wood at the same time for cooking, the concept of half baked food must have come into existence.

The half baked food consumed less fuel to cook, and when the food is half cooked the internal fire has to work more to digest the food ${ }^{3}$. So, the little amount of the half baked food was enough to satisfy the high amount of fire. When they eat pizza, they were knowingly giving their body heavy food.

\section{आहारमग्रिः पचति दोषानाहारवर्जितः। \\ धातून् क्षीणेशु दोषेषु जीवितं ढातुसद्ध्ष:ये॥ (अष्टांग हृदय ग्रहणी चिकित्सा 91)}

This is according to the principles of ayurveda, in ayurveda it is said that enough food to satisfy the hunger should be consumed 4 . If they eat fully baked food, the high amount of fire present will digest the cooked food in no time and it is possible that the fire will start digesting the body ${ }^{5}$ tissues later on if hunger is not satisfied according to the fire. To avoid dhatukshay, they started the consumption of heavy food.

\section{मात्राशी स्यात् । आहारमात्रा पुनरग्रिबलापेक्षिणी । | चरक सूत्रस्थान $5 / 3$}

This explains that quantity of diet depends upon the agni. Thus, high agni will require more food.

\subsubsection{MILK PRODUCTS INVENTION}

The other vikruti (forms) of milk like curd butter cheese they had to somehow use the food whatever they had that too sparingly because they do not have weather conditions favourable to grow vegetables on a daily basis and eat fresh, because due to extreme weather and snow nothing can be grown ${ }^{13}$.

They have to preserve the things; this is how the concept of frozen food might have arrived. They have no option other than ice and snow, and frozen things can be used later on.

\section{तथा पिष्टेक्षुक्षीरविकृतितिलमाषानूपौदकपिशितादीन्याहारद्रव्याणि प्रकृतिगुरूण्यपि मात्रामेवापेक्षन्ते । चरक सुत्रस्थान $5 / 5$}

These are explained as heavy food to digest and require more agni. This selection of food by them is exactly according to verse above, which fits their needs. 
Milk when was kept for a long time, it turned into curd 6 . That way the milk was wasted, it was of no use, to reduce wastage they looked for way to consume the milk turned to curd, they started utilizing that curd into cheese and butter. They do not have conditions like India where they can convert ghee from one kg of curd7, so they used it in a way the milk was not wasted.

Cheese helps them in two ways, firstly the wasted milk was converted into cheese which can be preserved for a longer time, and secondly, cheese is heavy to digest ${ }^{8}$.

So the conditions they were aiming at that the food should be heavy enough so the digestive fire will support it, they fulfilled their needs with different inventions, suitable and favourable for their lifestyle.

\subsubsection{THE CONCEPT OF RAW FOOD}

In ayurveda, the concept of eating raw food is said to be one of the things to be avoided and is rather explained to eat cooked food that is nutritious and easy to digest. Salad and fruits, the concept of raw food is not in ayurveda 11 but the westerners still survived well on fruits and salads, how? Again the same concept comes here. The cooked food cannot be kept for a longer time, it is light for digestion. Then what can stay for a longer time, the raw salad? Yes. They started eating it as the main part of their meals, as it was easily available and in less quantity their hunger was satisfied, also it saved fuel consumption.

\subsubsection{THE CONCEPT OF FRUITS}

In hilly regions lots of apple trees, cherries, berries, plums etc are there. They are heavy; hunger is certainly curbed when it is consumed. So apples and berries and such fruits were consumed in abundance later on in that region. Fruits are enough heavy as it's consumed raw, it makes us feel full with just a little amount of it. So, sweet fruits were fulfilling a larger part of the diet of many people in the hilly and cold region. And the abundance availability of such fruits in cold and hilly region made the consumption high now, around the other region too fruits were started consuming in large amount.

Availability

\subsubsection{THE SITTING HABITS}

In extremely cold climates it is not feasible to sit on the extremely cold surface, it was not comfortable. So they started using table and chair. So that they can avoid excessive cold, it was then when the concept of eating on the dining table came in ${ }^{10}$. It is not that they are doing anything opposite to ayurveda they are still following ayurvedic principles. Because sitting on the table and chair is far better than sitting in the extreme cold, which will ultimately harm them. So the westerners or their ancestors, they developed their lifestyle according to ayurvedic principles keeping in mind that smaller wrong is better than bigger wrong. So they have opted the ayurvedic principles in this way. This is the logic behind the inventions which look totally opposite to the ayurvedic principles but are extremely similar if we were to look further into it. There are references that before the invention of modern science the locally found herbs ${ }^{12}$ were used to treat people. Ayurveda also speaks of the same thing, that whatever herbs that are found in the region should be used for therapeutic purposes, so their treatment methods were also ayurvedic.

\section{DISCUSSION}

To study and understand the modified ayurveda in today's world, which we think is lost but deep down the roots come back to ayurveda. When we talk about ayurveda being lost in today's world and not finding anything relevant, to connect with. We need to find out that the roots that the people live lifestyle in keeping in mind the region a person lives in and the daily life conditions the people of that particular region face, which lead the ancestors of the people from that particular region modify scriptures in a way that, the teachings of the scriptures are revived back even today, hidden at the start of a new invention. Ayurveda speaks of the different use of ayurveda and according to the region which can differ so basically the western people have not exactly abandoned ayurveda but have revived the teachings instead, and have created their own way of using it. 
Vd. Jayashree Patil, and Vd. Nisar R Shaikh.

We have proof that ayurveda is universal, it is but seen in the little things of day to day life, it needs no research but minute observations and thinking keeping the lenses of ayurveda in account. It seems impossible on the surface but has roots even in eating and sitting habits too. It totally differs for sure, there are modifications but we need to look at the conditions which made these changes to happen.

\section{CONCLUSIONS AND RECOMMENDATIONS}

Ayurveda is a global science in every sense. It is deeply rooted in across the whole world. It is said to be a universal science as it exists in our day to day life, it may be in the modified way at some places but it does exists in different at every place in their own way, ayurveda is used with modification needed as per the condition of the climate or anything else.

\section{तच्च नित्यं प्रयुज्जीत स्वास्थ्यं येनानुवर्तते । अजातानां विकाराणामनुत्पत्तिकरं च यत्।। \\ चरक सूत्र $5 / 13$}

In this shlok, it is explained that everything that is necessary for keeping health in good condition should be done so that disease does not prevail. According to the conditions there the eating habits, the sitting habits were made to be changed in the way it won't be harmful or disease prevailing. It just has been a little different from its roots original ways but, as it speaks of survival even if it needs change it was done and in much better ways.

\section{SOURCES OF FUNDING}

This research received no specific grant from any funding agency in the public, commercial, or not-for-profit sectors.

\section{CONFLICT OF INTEREST}

The author have declared that no competing interests exist.

\section{ACKNOWLEDGMENT}

None.

\section{REFERENCES}

[1] https://www.eh-resources.org/the-role-of-wood-in-world-history/

[2] https://en.wikipedia.org/wiki/Famine\#Europe

[3] https://books.google.co.in/books?id=aFgCWevsaNcC\&pg=PA51\&lpg=PA51\&dq=half+baked+food+in+euro pe\&source=bl\&ots=aeYbJRui6a\&sig=ACfU3U3Fk_5tyG5q_04jMf2eKZvAwEvVKQ\&hl=en\&sa=X\&ved=2ahUK Ewi78Pm4wbjqAhVHVH0KHU6PDb0Q6AEwEnoECAoQAQ\#v=onepage\&q=half\%20baked\%20food\%20in\% 20europe $\& \mathrm{f}=$ false

[4] https://www.quora.com/How-long-do-we-take-to-digest-bread

[5] https://opencommons.uconn.edu/cgi/viewcontent.cgi?article=1025\&context=som_articles

[6] https://en.wikipedia.org/wiki/Curd\#: :text=Curd\%20is\%20a\%20dairy\%20product,then\%20allowing\%2 0it\%20to\%20coagulate.

[7] https://www.quora.com/How-much-milk-is-required-to-produce-1-kg-ofghee\#: :text=To\%20make $\% 201 \% 20 \mathrm{~kg} \% 20$ of,finally\%20boiled $\% 20$ to $\% 20$ make $\% 20$ ghee.

[8] https://www.nestandglow.com/healthy-food/food-digestion-times

[9] https://en.wikipedia.org/wiki/European_cuisine

[10] https://www.atlanticshopping.co.uk/inspiration-and-advice/history-of-dining-tables 
Review Study of Western World Lifestyle from the Ayurvedic Perspective

[11] https://www.geetavara.co.uk/blog-2/2019/7/22/the-ayurvedic-perspective-on-raw-

foods\#: :text=Ayurveda $\% 20$ generally $\% 20$ does $\% 20$ not $\% 20$ encourage,no\%20use $\% 20 \mathrm{in} \% 20$ our $\% 20$ syste m.

[12] https://www.who.int/bulletin/volumes/86/8/07-042820/en/

[13] https://www.gardeningknowhow.com/plant-problems/environmental/temperature-on-plants.htm 